\title{
Research Activity of Students of a Pedagogical Profile in Conditions of Smart Education
}

\author{
Nikolay I. Pak and Daria A. Barkhatova* \\ Krasnoyarsk State Pedagogical University \\ named after V.P. Astafyev \\ 89 Ada Lebedeva Str., Krasnoyarsk, 660049, Russia
}

Received 18.10.2016, received in revised form 19.05.2017, accepted 1.06.2017

\begin{abstract}
Smart Education technologies open new opportunities for development of students' research activity, allowing to make scientific base open and collective and also to apply new forms of the systematically distributed integration of scientists' forces. The cluster model of the international network science laboratory is offered for carrying out joint researches and project works on problems of education informatization while using Smart Education technologies. Network scientific communities will allow integrating personnel, material and technical resources of universities from different countries in the educational clusters. The latter will carry out joint scientific research and implement their results in educational process for ensuring new high quality level of research activity among students, school students and young scientists. As a result, the paper describes the International science laboratory experience at the Department of Informatics and Information Technologies in Education of Krasnoyarsk State Pedagogical University named after V.P. Astafyev.
\end{abstract}

Keywords: Smart Education technologies, students' research activity, international network laboratory.

The research is financially supported by Russian Humanitarian Scientific Foundation and Krasnoyarsk Region Fund (the scientific project No. 15-16-24007).

DOI: 10.17516/1997-1370-0114.

Research area: pedagogical sciences.

\section{Introduction}

Students' research activity is an integral part of educational process of any university, an indicator of its efficiency and work quality. Involvement of students in scientific activity has to provide integration of education, science and practice. In this case students will be able to apply all theoretical knowledge, which they learned in the training process, to try themselves as researchers, experimenter and creators, to reveal their creative potential and to define their further scientific trajectory, which can find its reflection in a final qualification work or dissertation. As Y.V. Belianina notes: "Research work of students is one of the most important means of improvement of future specialists' qualification, their capability to apply scientific and technical progress achievements in practical activities

(C) Siberian Federal University. All rights reserved

* Corresponding author E-mail address: nik@kspu.ru 
creatively, therefore, adaptability for the modern economy development" (Belyanina, 2011: 44).

The students' propensity to research activity is formed through doing laboratory and course works, degree projects, the organization and carrying out researches and experiments during their educational and work practice, through carrying out scientific research with university lecturers in circles, laboratories, etc. The research results can be shown at conferences and scientific seminars, presented at various competitions, forums, etc. However, during their exploration young researchers can face a number of challenges:

1. the limitations of the research base and the amount of knowledge available to the University;

2. difficulties of search for the similar works and need for elimination of paper duplication problem in the conditions of the "avalanche" growth of information amount;

3. high labor costs on forming an individual research trajectory for different students, preparing scientific training materials, selecting necessary information;

4. necessity of external experts search for solution of a number of problems in interdisciplinary researches.

Modern information technologies' possibilities open new prospects for the development of students' research activity, moreover, ideas of Smart Education allow making research environment open and collective and apply new forms of the systematically distributed integration of scientists' forces to carry out joint research.

In this regard the creation of the international network scientific and methodical university communities (laboratories, the centers, etc.) for carrying out joint research and project works on certain activities is considered worth applying the Smart Education technologies. Network scientific communities will allow integrating personnel resources, material base of universities from different countries for carrying out joint scientific research and introducing its results into educational process for further ensuring new high quality level of students' scientific and educational activity.

\section{Smart Education possibilities in the organization of research laboratory}

Smart Education is flexible training in the interactive educational environment with the application of the worldwide net free content. A key to understanding Smart Education is wide availability of knowledge and open educational resources. Only having shown some information to people, it is possible to attract their attention, to cause discussion and see a variety of approaches to a given problem (Tikhomirov, Tikhomirova, 2012). This feature is important for carrying out scientific research, as it opens huge opportunities for expansion and deepening of research results. Also the Smart Education technologies allow solving optimization problems of expenses and efforts, making scientific research more productive, eliminating duplication of similar works at different universities from different countries and enabling search for new models of the systematically distributed forms of the international interaction in the sphere of scientific and educational interuniversity cooperation and corporations.

Being an organizational form of students' research activity the Smart Education technologies open the way to creating the international network research laboratory, which corresponds to the demands of this educational paradigm:

- introduction of new educational technologies with the use of information and communications technology; 
- formation of the integrated real and virtual space;

- integration of the teaching staff potential;

- general information and education environment, individualization of educational trajectories (Fedulina, 2015).

These features of Smart Education permit distinguishing the principles of the international network laboratory's activity: interuniversity integration with the formation of uniform electronic space of knowledge and achievements of universities, an individualization of students' research trajectory, expansion of the practicefocused environment due to the involvement of schools and IT-business.

S.A. Pisareva remarks that today development of pedagogical education cannot occur in separate universities independently. Only integration of efforts can give significant effect, showing society the uniqueness of the Russian system of teachers training and the importance of support for its further development. Interuniversity interaction is a traditional form of cooperation concerning education development in Russia and abroad as education gets new forms today (Pisareva, 2011: 3).

Interuniversity integration will let students master the skills of scientific interaction in order to achieve certain results, develop communicative qualities, and make new scientific and educational contacts. Modern information technologies will offer not only solutions to overcome distance, but also to overcome a language barrier. Features of interaction in electronic space enable to develop ICT competence of students and teach them how to determine a problem, build objects and describe the study results at the new qualitative level, demanding the greater accuracy and space saving.

Moreover, the cooperation supports universities in developing academic mobility of students which is also an indicator of the university's activity effectiveness. Participating in conferences, presenting their achievements, students gain experience in public speaking, learn how to present result in the concise, visual form. To prove their ideas it is necessary to be able to reason, systematize, generalize material, to distinguish between main and minor factors. Moreover, the presentation of results on a "foreign territory" gives the possibility to receive an independent assessment of the activity, to get acquainted with colleagues' works and find new ideas for further project development.

The benefits and advantages of collaboration of universities and schools are described in researches of R.H. Clarken (2001), T. Kruger et al. (2009), C.O. Wasonga et al. (2011), where they affirmed that both the university and the schools gain mutual benefits from the interactions. Opolot-Okurut et al. underlined that university-school partnerships serve several purposes such as opening channels for sharing ideas and information, initiating, maintaining and upholding an open two-way communication system between the collaborating members (Opolot-Okurut et al., 2014: 844).

The laboratory activity cannot take place without schools' participation, because most of the research while educating future teachers of computer science is aimed at solving problems of school education system, therefore the formation of projects should unite the teachers and the students. The school is also the base of testing research results. Involvement of future teachers of computer science in the professional environment fosters developing professional skills of the future specialists. Thus, internal participation in school pedagogical process is not necessary, because modern information and communication technologies allow managing lessons, surveys, diagnostics, meetings with teachers, etc. in the remote mode. 
The following important component of laboratory mentioned above is UniversityBusiness collaboration, which was justified in papers of N.I. Pak (2014) and T. Wilson (2012).

Professor Wilson (2012) reviewed that the university sector cannot achieve excellence in its functions by itself; a sustainable supply chain is not a simple linear supplier-purchaser model. Supply chains that excel in performance are those where collaboration is strong and resilient; where there is constant communication in both directions, both operational and strategic; where there is a common understanding of the objectives of the other party; where there is a willingness to change existing practices to meet the needs of the collaborators; and where the boundaries of capability are transparent and respected (Wilson, 2012: 13).

Involvement of IT-firms expands a platform for practical application and development of information and computer products, allows to solve a number of problems with information support and maintenance of laboratory's activity, and also to introduce students to the real market of the IT-industry.

This collaboration and integration of universities, schools and IT-business are most effective in conditions of information technology usage, especially in conditions of Smart Education technology, which brings lots of benefits for making joint research in virtual laboratory, saving resources and costs.

Technological progress is transforming some of the traditional channels, especially those dependent on repeated personal contact and exchange of information. Virtual networks enable greater collaboration between researchers and industry in the exchange and sale of IP. Open access journals provide a complementary channel for disseminating scientific results, while open research data initiatives that make research available for further investigation or innovation represent a new knowledge transfer channel (Cervantes et al., 2014: 75).

In modern conditions of the personalityoriented technologies the individualization of students' research trajectory seems critical. The individualization allows solving a number of problems with a selection of research means and carrying it out. Firstly, a choice for the research topic in the international laboratory will not depend on the subject of projects carried out at the university, where this student studies. Secondly, the wide choice of projects gives the student a chance to choose the direction which is interesting to him/her and where he/she already has an experience. And thirdly, the complete dependence of the student on the research supervisor disappears. Also, the student can work on the part of research, solving only one problem of a "big" project.

In this way, the international research network university laboratory is the cooperation of students, graduate students, teachers, pupils and lecturers from different countries with involvement of experts from IT business for implementation of both theoretical and practical projects in the conditions of electronic space. Collaboration of laboratory participants makes provision for achieving better results by joint forces, for covering larger audience, at which the project is targeted, for setting bigger importance to the project from the point of view of social, scientific and technical aspect.

Making conclusions, it may be noted that Smart education requires serious pedagogical thinking, the introduction of new pedagogical development, that will intensify the educational process and improve its quality (Fedulina, 2015). It is necessary to review the developed approach to students' research work: change the forms of its organization, increase the number of research projects, in which the student can take part, 
provide open access to students for acquaintance with laboratory project work.

\section{Model of network international research laboratory in the system of pedagogical education}

The international network laboratory is formed by creation at partner universities of its Offices and Representations, which have the double status:

- in university and the country - the status of the International laboratory in the international space;

- globally - the status of Office or Representation of joint International laboratory.

The structure of laboratory can be presented in the form of three contours of interaction: University cooperation, interaction with schools and IT-business (Fig. 1).
Council of research supervisors manages the laboratory's activity. Council of research supervisors includes research supervisors of offices and scientific groups. The council is led by the Head of the laboratory appointed by the Academic Council of the UniversityCoordinator in consultation with the Academic Councils of universities participating in a new laboratory. Head of the laboratory and the Council develop annual plans of the laboratory and make reports.

Universities give joint lessons for teaching students to do research, share the best practices, and hold master classes. Thus, the knowledge exchange can occur not only from a teacher to a student, but also from a student to a student that seems to be the most effective method of knowledge assimilation. Information transfer can be carried out both online with the use of

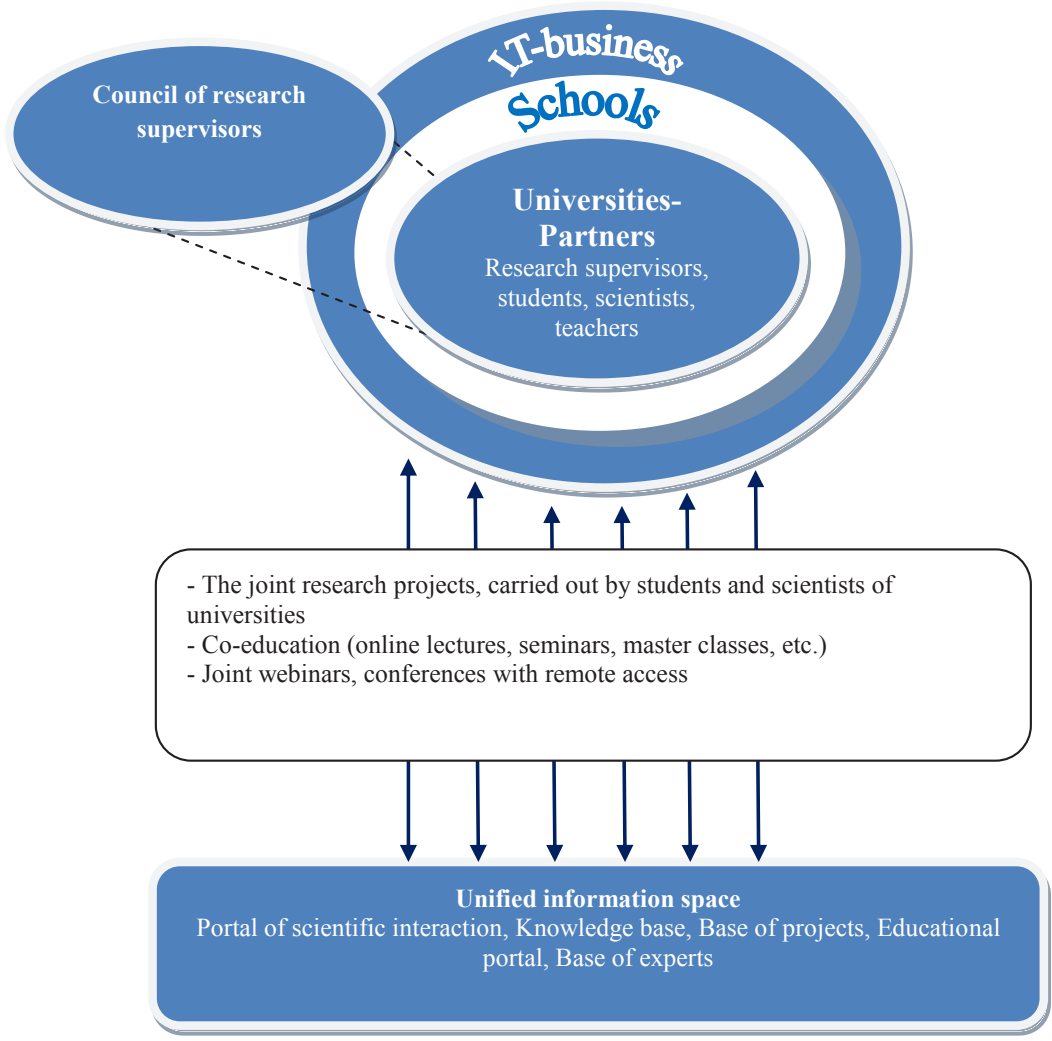

Fig. 1. Model of network international laboratory in the pedagogical education 
modern communication technologies and the Internet services and offline with the use of information in a unified information portal of the laboratory.

The laboratory's information portal is the information support system of scientific activities of laboratory participants, which is realized according to the achievements of Smart Education technologies. The portal main idea is collaboration of scientists, teachers, students and businessmen from different countries for the purpose of implementing joint projects interesting to each participating party.

The information portal should include the news feed, announcing the main achievements of laboratory participants, the upcoming and passed scientific and training events, etc. News can be provided according to the categories of laboratory participants: for young scientists, research supervisors, students, teachers, businessmen.

Also it is necessary to include sections: scientific actions (conferences, webinars, etc.), training (abstracts of courses, provided by laboratory, a schedule of virtual classes).

An important component of system is the back office, because it will create the personally oriented information environment for laboratory participants. Users can look through profiles of other participants, find adherents, communicate in the virtual environment regardless of the place and time, to submit their works to the participants' approval, etc.

In the back office laboratory participants will also be able to send papers for the publication in the journals and proceedings of laboratory conferences. Here it is also possible to receive the review on paper.

The portal should include a bulletin board where users will be able to add their ads and search for scientific deficits. For example, on the website it might be possible to find a specialist in 3D-graphics, the website creation, or the translation of paper into a foreign language, etc.

The unified information portal provides access to information and to news of laboratory for laboratory participants. Also on the portal it shall be possible to see all existing projects, which are carried out within the laboratory, to study the available projects' content, to estimate development prospects.

The laboratory holds webinars and conferences to familiarise participants with students' researches. Universities interact with schools and IT-firms for approbation of projects. Also specialists of IT-business provide the project with technical functionality at the necessary level.

In this way, the research laboratory for students of pedagogical education allows:

1. Creating the environment, where the students can generalize the gained knowledge during studying at university, reveal their creative potential, express ideas about possible ways to solve the problems connected to training process and bring them to life;

2. Dialogue between the teachers and the students permitting to organize exchange of experience, entering of fresh ideas into scientific activity of universities;

3. Creating a new research team, capable to provide achievement of practical results in the education system with involvement of schools, other educational institutions, and also experts from IT-business;

4. Students' involvement in research with division of responsibilities and a circle of tasks, providing achievement of uniform result;

5. Teaching students to determine actual problems, ways of their solutions, continuity of research results in professional and educational activity, and also ways of description and representation of the project's results. 
For achievement of assigned tasks several projects have to be realized in research laboratory, so that students could choose any direction, depending on their interests.

\section{Some results of students' research activity (future teachers of informatics) in KSPU named after V.P. Astafyev}

Experience of the organization of research laboratory for future teachers of Informatics in Krasnoyarsk State Pedagogical University named after V.P. Astafyev has shown the students' interest in this activity. There are current students' projects:

1. Natural tutorials of Informatics with application of the 3D technology (modelling of the principles of digital devices work; development of simulators for studying the mathematical fundamentals of Informatics; development of special training packages for learning the basics of programming (data manipulation in reality).

2. "Smart" educational resources (creation of the unified educational space, constructed on the principles of mental didactics - cloud technologies in education, development of visual tutorials, development of unified cloud space for studying of Informatics at various levels).

3. Cognitive informatics (diagnostics of cognitive abilities; development of cognitive models; development of mental expert systems).

4. Competitive robotics (Robotank biathlon; development of the virtual environment for organization "Robotank Biathlon").

The robotank biathlon is the didactic game organized in the form of a tournament between students of various training levels, so it does not depend on the participants' knowledge level.

The main idea of the project is that pupils and students not only create "robotanks" on various platforms for participation in biathlon, but also they are involved in development of game infrastructure, its information and technical maintenance. For the technical support of the project IT firms are also attracted; they help to organize the game and show a real place of robotics in life.

Students and teachers of pedagogical university are engaged in preparation of working area and the content of carrying out "Robotank Biathlon". During the organization and approbation of working area students get to know robotics bases by themselves, learn to set didactic tasks, build didactic games with the application of robotics.

The Robotank Biathlon project is the longterm project whose contents can be changed, but the main idea remains the same - cooperation of educational institutions and IT companies for continuous development of the environment of students training with robotics on their own (Barkhatova, 2015: 97).

The special interest is the organization of interaction with schools in the Megaclass project. The Megaclass is a methodical system of teaching and educational activity of different schools in the information and education environment of cloud services on the basis of integrating scientific, teaching and educational processes of Pedagogical University, educational institutions, municipal departments of education with the application of electronic training and remote technologies.

The essence of this methodical system is creating an educational cluster of "SchoolPedagogical University" in which training of pupils and students, professional development of teachers on workplaces are integrated into unified educational process by means of network and cloud services and video conferencing. Training is provided within online megalessons of specific disciplines.

The megalesson is given at the same time at all schools of a cluster, with participation of the teachers and the students, who together with the 
teachers prepare the next lesson and carry it out according to the concept of a network course. The cloud presents portals of learning tools (mental textbooks, video lectures, etc.), diagnostics of training quality, pupils' competences, development of pupils, students and teachers in actual problems of science and society (Project "Megaclass"..., 2016).

Today our international scientific laboratory integrates students, scientists and teachers of the Krasnoyarsk State Pedagogical University named after V.P. Astafyev, Siberian Federal University, Siberian State Aerospace University named after M.F. Reshetnev, Abai Kazakh National Pedagogical University, Josip Juraj Strossmayer University of Osijek (Croatia), also pupils, teachers of the Krasnoyarsk and Kazakhstan schools and experts of IT firms.

The information portal for the interaction of laboratory participants is being developed at the moment.

\section{Conclusion}

The organization of students' research activity in a university faces a number of objective and subjective difficulties.

Possibilities of modern information technologies open opportunities for the development of students' research activity on the basis of corporate and cooperative interuniversity and international integration.

Experience of organization of students' research in KSPU (Faculty of Informatics) with attraction of a number of Krasnoyarsk universities, schools and IT-firms, and also foreign partners showed the possibility of achieving high efficiency.

Consequently now the university is forming the network international scientific laboratory of problems of education informatization and training technologies with participating universities from Russia, Kazakhstan and Croatia for ensuring new high quality level of scientific and educational activity of students.

\section{References}

Barkhatova, D.A. (2015). Proekt "Robotankovyi biathlon" kak tekhnologiia obrazovaniia budushhego [Project "Robotank biathlon" as the future educational technology], In Materialy konferentsii po nauke i texnologiiam SNG-Koreia 2015 [Materials of 2015 CIS-Korea Conference on Science and Technology], 97-98. Moscow.

Belynina, Y.V. (2011). Nauchno-issledovatel'skaia rabota studentov: rukovodstvo, organizatsiia, formy (1946-1955) [Students research work: management, organization, forms], In Omskii nauchny vestnik [Omsk scientific bulletin], 3(98), 44-46.

Cervantes, M., Meissner, D. (2014). Commercialising public research under the open innovation model: new trends, In Foresight, 3(8), 70-81.

Clarken, R.H. (2001). Toward more effective education through university and school collaboration, available at: https://rodclarken.files.wordpress.com/2011/09/toward-more-effectiveeducation.pdf (accessed 5 September 2016).

Fedulina, S.B. (2015). Innovatsionnye protsessy $v$ obrazovanii, sviazannye $s$ razvitiem informatsionnykh $i$ kommunikatsionykh tekhnologii [The innovative processes in education connected with the development of information and communication technologies], available at: http://www. rusnauka.com (accessed 15 September 2016).

Kruger, T., Davies, A., Eckersley, B., Newell, F. \& Cherednichenko, B. (2009). Effective and sustainable university-school partnerships: Beyond determined efforts by inspired individuals, 
available at: http://www.aitsl.edu.au/docs/default-source/default-document-library/effective_and_ sustainable_university-school_partnerships (accessed 10 October 2016).

Opolot-Okurut, Charles \& Juliana Bbuye (2014). School-University Collaboration Initiative: Benefits and Challenges in Uganda, In American Journal of Educational Research, 2.10, 843-849.

Pak, N.I. (2015). Innovatsionnaia tekhnologiia "Mega-klass" kak sinergeticheskoe sredstvo obucheniia v obrazovatel'nykh klasterakh [The innovative Megaclass technology as the synergetic tutorial in educational clusters], In Informatizatsiia obrazovaniia - 2015: Materialy mezhdunarodnoi nauchno-prakticheskoi konferentsii [Education informatization - 2015: materials of the international scientific and practical conference], 288-294. Kazan.

Pak, N.I. (2014). Strategii informatsionnogo podkhoda v proektirovanii klasternoi sistemy obrazovaniia "Shkola-Pedvuz" [Strategy of information approach in designing of the cluster education system "School-Pedagogical university"], In Fundamental'nye nauki i obrazovanie: Materialy II mezhdunarodnoi nauchno-prakticheskoi konferentsii [Fundamental sciences and education: Materials II of the international scientific and practical conference], 66-76. Biysk.

Pisareva, S.A. (2011). Gertsenovskii universitet v sisteme mezhvuzovskoi integratsii v oblasti pedagogicheskogo obrazovaniia [Herzen university in the system of interuniversity integration in areas of pedagogical education], In Universum: Vestnik Gertsenovskogo universiteta [Universum: Bulletin of Herzen university], 10, 3-8.

Project "Megaclass": Achinsk cluster (2016). Krasnoyarsk State Pedagogical University named after V.P. Astafyev. Basic department of Informatics and information technologies in education, available at: http://www.kspu.ru/page-11671.html (accessed 10 October 2016).

Project "Robobiathlon" (2016). Krasnoyarsk State Pedagogical University named after V.P. Astafyev. Basic department of Informatics and information technologies in education, available at: http://www.kspu.ru/page-16363.html (accessed 10 October 2016).

Research seminar-webinar "Information technologies and open education" in KSPU named after V.P. Astafyev (2016). Krasnoyarsk state pedagogical university named after V.P. Astafyev. Basic department of Informatics and information technologies in education, available at: http://www.kspu. ru/page-11660.html (accessed 10 October 2016).

Tikhomirov, V.P., Tikhomirova, N.V. (2012). Smart education: new approach to a development of education, available at: http://www.elearningpro.ru/forum/topics/smart-education (accessed 21 September 2016).

Smart education - new philosophy of education (interview with the research supervisor of Moscow State University of Economy, Statistics and Informatics Vladimir Tikhomirov) (2010). "Your partnerconsultant", 50 (9366), available at: http://www.eg-online.ru/article/120870 (accessed 21 September 2016).

Wasonga, C.O., Rari, B.O. \& Wanzare, Z.O. (2011). Re-thinking school-university collaboration: Agenda for the 21st century, In Educational Research and Reviews, 6(22), 1036-1045.

Wilson, T. (2012). A Review of Business-University Collaboration, available at: https://www.gov. uk/government/uploads/system/uploads/attachment_data/file/32383/12-610-wilson-review-businessuniversity-collaboration.pdf (accessed 21 September 2016). 


\section{Научно-исследовательская деятельность \\ студентов педагогического профиля \\ в условиях образования Smart Education}

Н.И. Пак, Д.А. Бархатова

Красноярский государственный педагогический университет им. В.П. Астафьева

Россия, 660049, Красноярск, ул. Ады Лебедевой, 89

Tехнологии Smart Education открывают новые возможности для развития научно-исследовательской деятельности студентов, позволяя сделать научную базу открытой и коллективной, а также применить новые формы системно-распределенных интеграчий сил ученых. Предложена кластерная модель международной сетевой научно-исследовательской лаборатории для проведения совместных исследований и проектных работ по проблемам информатизаиии образования с применением технологий Smart Education. Сетевые научные сообщества в условиях образовательного кластера позволят интегрировать кадровые ресурсы, материально-техническую базу университетов разных стран для проведения совместных научных исследований и внедрить их результаты в учебный процесс для обеспечения нового качества научно-исследовательской деятельности студентов, школьников и молодых ученых. В качестве результата приводится опыт организации Международной научно-исследовательской лаборатории на базе кафедры информатики и информационных технологий в образовании Красноярского государственного педагогического университета им. В.П. Астафьева.

Ключевые слова: Smart Education технологии, научно-исследовательская деятельность студентов, международная сетевая лаборатория.

Исследование финансируется Российским гуманитарным научным фондом и Фондом Красноярского края (научный проект № 15-16-24007).

Научная специальность: 13.00.00 - педагогические науки. 